\title{
Characterization and profile of adults with spinal cord injury treated at a physiotherapy school clinic in the interior of the State of Pernambuco - Brazil
}

\author{
Elizama Rafaella dos Santos ${ }^{1}$; Lísley Nayara Alves de Lima ${ }^{1}$; Natália Paula Silva de Lima ${ }^{1}$; Saledja \\ Rodrigues dos Santos'; Thaísa de Souza Silva ${ }^{1}$; Sâmia Dayana Lemos de Lacerda ${ }^{2}$; Bruna Rafaela \\ Dornelas de Andrade Lima Monteiro*2
}

1 Students of the Physiotherapy course at UNIFACOL - University Center FACOL Faculty Writer Osman Lins, Vitória de Santo Antão, Pernambuco, Brazil.

2 Professor of the Physiotherapy course at UNIFACOL - University Center FACOL Faculty Writer Osman Lins, Vitória de Santo Antão, Pernambuco, Brazil.

E-mail adresses: brunadornelasmonteiro@gmail.com (Bruna Rafaela Dornelas de Andrade Lima Monteiro)

*Corresponding author

\section{To cite this article:}

Santos, E.R.S.; Lima, L.N.A.; Lima, N.P.S.; Santos, S.R.; Silva, T.S.; Lacerda, S.D.L.; Monteiro, B.R.D.A. Characterization and profile of adults with spinal cord injury treated at a physiotherapy school clinic in the interior of the State of Pernambuco - Brazil. International Journal of Sciences. Vol. 2, No. 1, 2021, pp. 51-54. ISSN 2763-5392.

Received: 06 29, 2021; Accepted: 06 30, 2021; Published: 07 15, 2021

\begin{abstract}
Spinal cord injury (SCI) is an invaluable public health problem, with an incidence of 40 to 80 injuries per million people per year, resulting in trauma, disease or birth defect that causes changes in sensitivity and motor function, whose impairments depend on the level reached. The aim of this study was to characterize the cause and level of SCI, as well as to describe the age group and gender of these patients seen at a Physiotherapy School Clinic in the state of Pernambuco in 2020. This is an exploratory, descriptive and quantitative study. Forty-two medical records of patients in the neurology department of the school clinic were analyzed and those with a closed diagnosis of SCI were included. After evaluating the eligibility criteria, 9 patients were included in the research. The collected data were analyzed, interpreted and exposed through graphs and demonstrated by mean or percentage. It is concluded that the study confirms the highest prevalence of complete TYPE LM, thus being the majority of wheelchair patients. Thoracic injury was the most common level and the main etiology was gunshot wound. All medical records evaluated were of male patients, with a mean age of 39 years.
\end{abstract}

Keywords: Spinal cord trauma; Spinal cord; Asia

\section{Introduction}

Among all the disabilities that can happen to a human being, one of the most complicated and difficult is spinal cord injury due to the physiological importance of the medulla to transmit brain impulses and messages to the whole body, and also as a nerve center in itself, where there is a control of bodily functions, from posture to thermal regulation. When there is an injury, it generates an interruption of the passage of information resulting in important functional disabilities [1].

Spinal cord injury (SCI) is the result of trauma, a disease or a congenital defect, with changes in sensitivity and motor function, depending on the extent and location of the same. The limitations manifested will depend on the level reached, with movements and bodily sensations partially reduced or totally lost below the level of the injury [2]. They have several etiologies and the more proximal to the brain, the greater the severity [3].

The lesão of the spinal cord affects millions of people in the world and has lifelong consequences [4]. Congenital LM (Myelomeningocele or Spina Bifida) is a malformation that is o), an imperfection in neural tube closure. When this closure does not occur, the lumbar or thoracic region of the spinal cord is exposed, damaging it. [ Non-traumatic spinal cord injury is identified by several factors such as: tumors that compress the spinal cord; vascular accidents; herniated disc; deformities in the spine that compress or decrease blood supply to the spinal cord [6]. Spinal Cord Trauma (MRTr) or Traumatic Spinal Cord Injury, comes from car accidents, diving or fall from height. It is defined by a trauma that 
fractures or displaces one or more vertebrae of the spine causing an entrance into the medullary canal and reaching the spinal cord by compression or section [7]. It can be classified according to the sensory-motor impairment that the person presents. When the spinal cord suffers an injury, it can be partially or fully affected and, thus, its degree of involvement is determined. An injury is classified as complete when there is no preserved motor or sensory function in the sacral segment. In an incomplete lesion, motor and sensory functions are preserved at the level of the sacral segment [8].

The severity and degree of permanence of the motor deficit and/or sensory depend on the extent, location and damage that was caused to the tissue. If the initial lesion is just a hematoma or a contusion the spinal cord, there may be some preservation of the tissue, resultants in the retention of function, being an incomplete lesion. When there is a transection through the spinal cord, it results in a complete injury, and a separation between the spinal cord and its segments may occur, causing total loss of motor and sensory function [9].

In relation to the level, it may compromise the four limbs, causing a tetraplegia, or may compromise the lower limbs resulting in a paraplegia. The classification of the spinal cord injury for the evaluation of sensitivity and motricity was standardized by the classification scale of the American Spinal Injury Association (ASIA) through the thresholds a to E, being: ASIA A (complete spinal cord injury), ASIA B (complete and incomplete sensory motor injury), ASIA C (incomplete sensory and motor injury), and ASIA D (incomplete lesion with motor function preserved below the level of the lesion) [10].

In order to have a good rehabilitation, the intervention must be directed and evaluated so that it has a good functioning of the system in general, restoring or replacing the functions lost in order to reintegrate the individual into society. It is essential to establish a functional prognosis early so that all those involved can help to achieve realistic objectives and start planning their social reintegration from the outset [11]. In addition to the numerous visible traumas, there are also generalized consequences for numerous or truncations, such as the functioning of the bladder, intestine, respiratory system, cardiovascular and sexual function. In addition to the social, financial and psychological implications, there is a susceptibility of the injured to ter surgical complications in old age, musculoskeletal injuries, pain, osteoporosis and other problems. People with SCI require not only initial medical care and rehabilitation, but also for tend they need continuous wheel chair use, adapted environments, adequate home care, equipment, transportation, employment and financial support. The management of people with SCI is therefore complex, involving many health professionals, organizations and government services [12].

\section{Methodology}

This is an exploratory, descriptive and quantitative study. The medical records of patients treated with clinical diagnosis of Spinal Cord Injury were evaluated in a Clinical School of the Interior of the State of Pernambuco - Adult Neurological Physiotherapy Sector in the year 2020. Medical records that did not have a closed diagnosis of SCI were excluded. After the evaluation of the eligibility criteria, 9 patients were included in the study. The collected data were analyzed, interpreted and exposed through gráficos and demonstrated by mean or percentage

\section{Results and Discussions}

After analyzing the 42 medical records, it was found that all patients diagnosed with SCI treated at the school clinic were male.

Regarding the age group, among the evaluated, the average age was 39 years, with a minimum age of 19 and a maximum of 60 years. When divided into groups with 15 years of difference between them (from 19 to 30 years; 31 to 45 years; 46 to 60 years), it was seen that the percentage was the same in the three groups, resulting in $33.3 \%$ (Figure 1) of the medical records analyzed in each group.

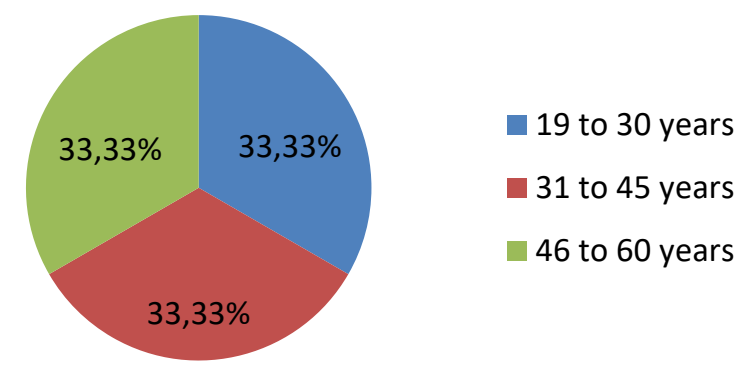

Figure 1. Distribution of patients by age group

Regarding the types of SCI, $66.66 \%$ of the medical records analyzed had the complete lesion (Figure 2), and the equivalent of 06 patients, already with incomplete lesion, 03 patients were found, corresponding to $33.33 \%$ of the cases.

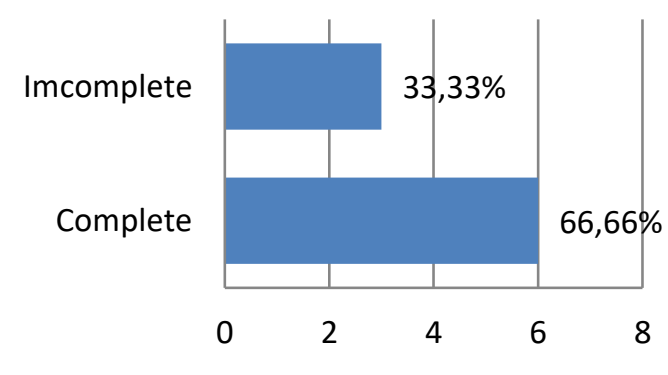

Figure 2. Type of Injury

Regarding the cause of the injury (Figure 3), among the 09 medical records analyzed, 05 etiologies were found: fall (22\%), firing of a firearm $(34 \%)$, tumor $(11 \%)$, automobile accident $(22 \%)$ and perforation by sing gun $(11 \%)$. 


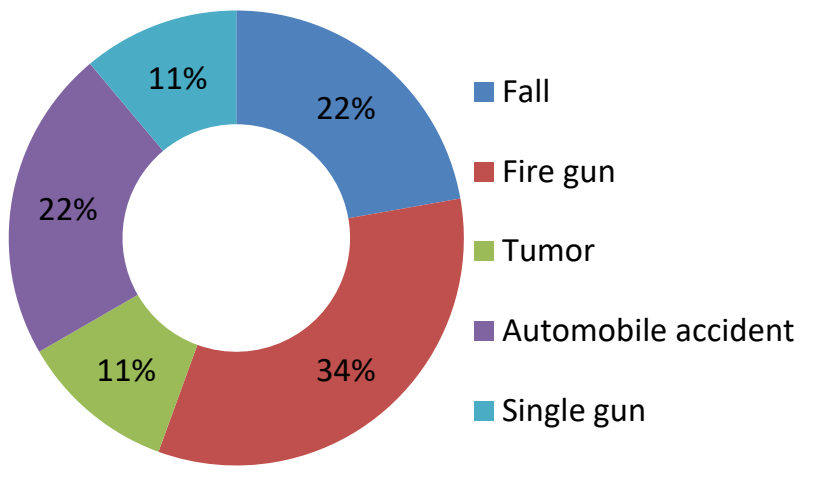

Figure 3. Injury Etiology

Among the 9 patients evaluated, 3 of them walk with the aid of crutches and a walk, corresponding to $33 \%$, and $6(67 \%)$ do not walk, using a wheelchair for locomotion (Figure 4).

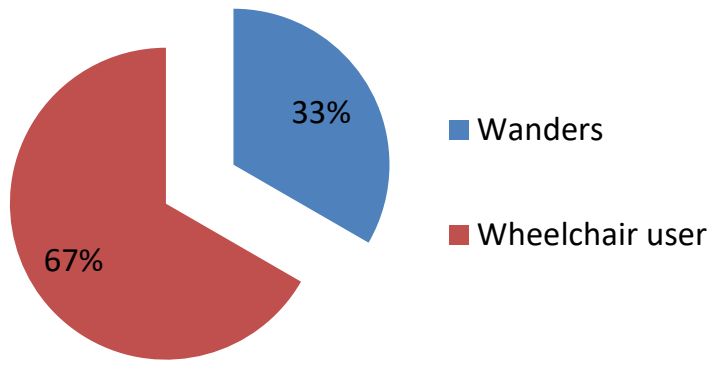

Figure 4. Locomotion

The level of injury (Figure 5) permeates the cervical region and the lumbar region. $11.11 \%$ occurred in the cervical region, $44.44 \%$ in the thoracic region, $22.22 \%$ in the lumbar region and $22.22 \%$ were not described in the medical records.

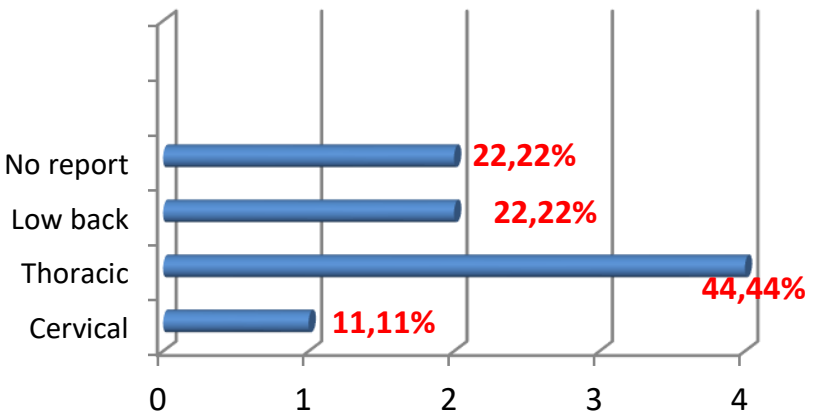

Figure 5. Injury level

\section{Discussions}

Based on the results found in the study, the age group (Graph 1) of patients with spinal cord injury in the school clinic is 19 to 60 years, all of them male. Of the 09 patients seen, 06 presented complete spinal cord injury (Graph 2), using a wheelchair.
The trauma caused by spinal cord injury has a great impact on human development, but it is not necessarily something that leads to death, but there is a great change and limitation in the lifestyle of the affected person. This trauma can result in a partial or complete rupture of the nerve bundles of the spinal cord, which can cause some losses and/or complications, such as lack of control of the sphincters, motor, sexual and sensory problems and functional problems, compromising thermal, circulatory and respiratory functions, in addition to spasticity and pain [13].

According to Cardoso 2018, spinal cord injury is responsible for developing a severe chronic disease and physical disability, causing significant neurological alterations. Characterized by motor, sensory and neurovegetative disorders of the body segments located below the lesion, compromising superficial and deep sensitivity, motricity and autonomic functions [14].

One author mentions in his study that each year there are more than 10,000 new cases of spinal cord injury, and trauma is the main cause, which corresponds to a high incidence, when compared to other countries [15]. It is undoubtedly a pathology of great and socioeconomic impact, reflecting in high costs for health services [16].

The present study corroborates the data presented by Nogueira et al [17], which refer to gunshot wounds with being the main cause of SCI. According to Mansini [18], traffic accidents represent the most frequent causes. The increase in the fleet of vehicles, human failures and inadequate or insufficient laws, are events that contribute to this epidemiological data.

Buhler. M. et al. (2001) [19] studying the profile of cases of patients assisted in the disability care center (CAD), observed that the greatest cause of spinal cord injury was fall, followed by car accident. The present study corroborates the results found.

\section{Conclusions}

From the results presented, it is concluded that the patients with SCI treated at the Physiotherapy School Clinic located in the state of Pernambuco - Adult Neurology Sector in the year 2020 were adults, all male. The study confirms the highest prevalence of complete TYPE SCI, thus being the majority of wheelchair patients. The level of thoracic injury was the most prevalent among the medical records analyzed and its main etiology was gunshot wounds. Physiotherapy assists in rehabilitation in a targeted and specific way aiming at the functional independence and quality of life of these patients.

\section{References}

[1] FARIA, F. Lesões vértebro-medulares - A perspectiva da reabilitação. Revista portuguesa de pneumologia, 2006.

[2] CARDOSO, F. L. et al. Fatores associados à satisfação sexual de homens com lesão medular. Fisioterapia e Pesquisa. p. 3542. Vol 25, 2018. 
4 Santos, E.R.S.; Lima, L.N.A.; Lima, N.P.S.; Santos, S.R.; Silva, T.S.; Lacerda, S.D.L.; Monteiro, B.R.D.A. Characterization and profile of adults with spinal cord injury treated at a physiotherapy school clinic in the interior of the State...

[3] SILVA, G. A. et al. Avaliação funcional de pessoas com lesão medular: utilização da escala de independência funcional; Florianópolis, 2012.

[4] KJELL, J. \& OLSON, L. Rat models of spinal cord injury: from pathology to potential therapies. The Company of Biologists, 2016.

[5] LIANZA, S. Órtese de propulsão recíproca modelo argo método de avaliação, tratamento e análise de resultados na reeducação da locomoção em pacientes com lesão medular; p. 27, São Paulo, 1997.

[6] LOUREIRO, A. P. et al. Lesão medular: reabilitação e qualidade de vida. Fisioterapia após lesão medular; 2012.

[7] BRITO, L. M. O. et al. Avaliação epidemiológica dos pacientes vítimas de traumatismo raquimedular. Rev. Col. Bras. Cir., v.38, p. 304-309, 2011.

[8] HARTMANN, A. P.B.J et al. Diagnóstico por imagem na avaliação da ossificação heterotópica. Rev. Bras. Reumatol., São Paulo, v. 44, n. 4, p. 291-293, Aug. 2004.

[9] FEINBERG, H. R. S. \& HOULE, J. D. Exercise after Spinal Cord Injury as an Agent for Neuroprotection, Regeneration and Rehabilitation. Brain Research, 2016.

[10] SILVA, G. A. et al. Avaliação funcional de pessoas com lesão medular: utilização da escala de independência funcional; Florianópolis, 2012.

[11] FARIA, F. Lesões vértebro-medulares - A perspectiva da reabilitação. Revista portuguesa de pneumologia, 2006.

[12] HARVEY, L. A. Physiotherapy rehabilitation for people with spinal cord injuries. Journal of Physiotherapy, 2016.

[13] MURTA, S. G.; GUIMARÃES, S. S. Enfrentamento à lesão medular traumática. Rev Universidade de Brasília Estudos de Psicologia; v. 24, p. 196-202, 2007.

[14] CARVALHO, H. P. et al. Novas perspectivas de fisioterapia respiratória em lesão medular - uma revisão sistemática. Acta Paul Enfermagem. p. 554- 564. Vol 3, 2017.

[15] MASINI, M. Estimativa da incidência e prevalência de lesão medular no Brasil. Jornal brasileiro de neurocirurgia; v. 34, p. $12-17,2018$.

[16] NUNES, M.D.; MORAIS, R.C.; FERREIRA, G.C. Fisiopatologia da lesão medular: Uma revisão sobre os aspectos evolutivos da doença. Getec; p. 87-103, 2017.

[17] NOGUEIRA, P. C. et al. Perfil de Pacientes com Lesão medular traumática e ocorrência de úlcera de pressão em um hospital universitário. Ver.Latino-am Enfermagem, 2006.

[18] MASINI, M. Tratamento de fraturas e luxações da coluna toracolombar por descompressão póstero-lateral e fixação posterior com retângulo e fios segmentares sublaminares associados a enxerto ósseo; São Paulo, 2000.

[19] BÜHLER, M. A. et al. Perfil clínico e epidemiológico dos pacientes atendidos no centro de atendimento à deficiência (CAD); Rev de Literatura, 2001. 